\title{
Stimulering av motorisk hjernebark mot smerter
}
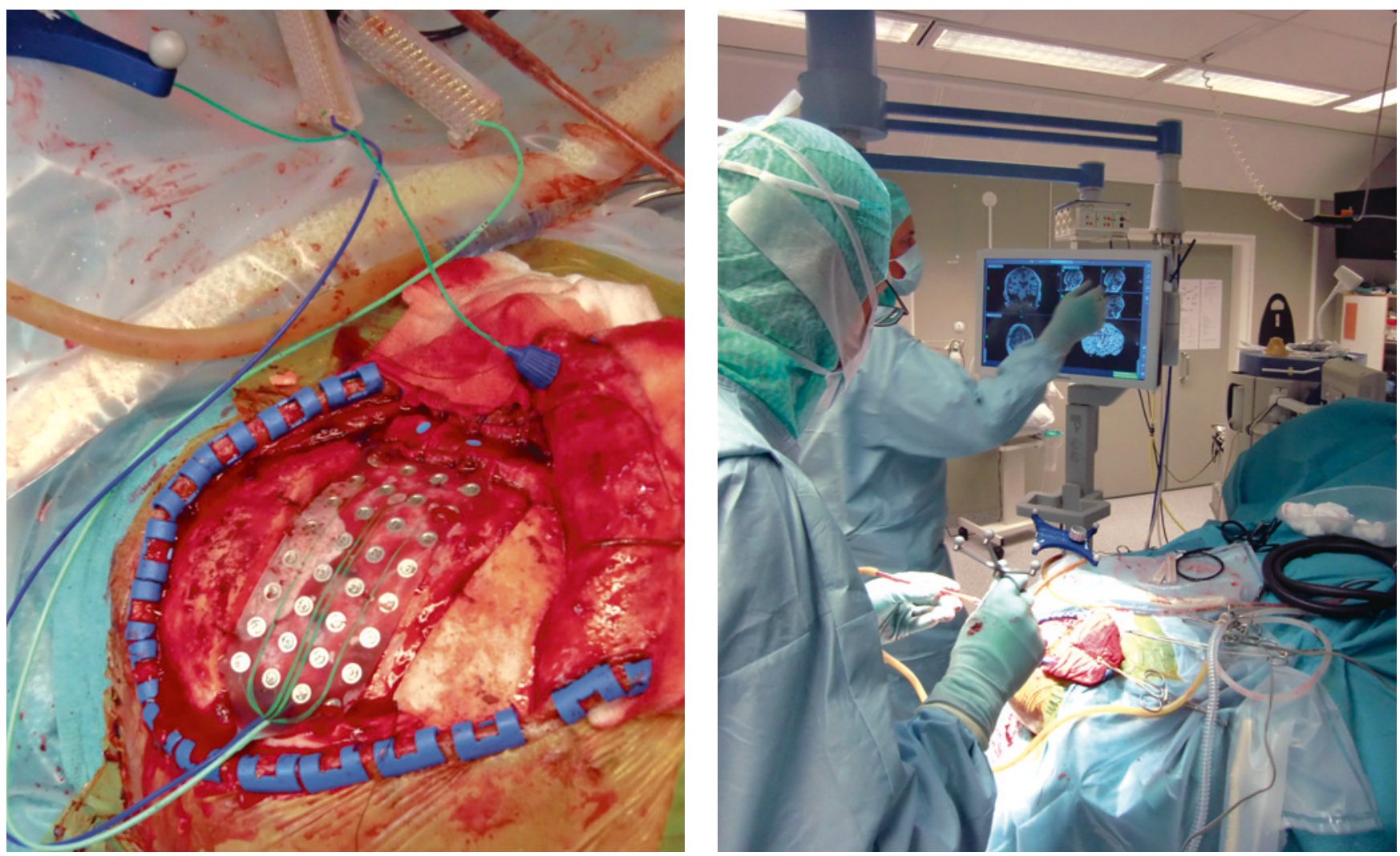

En pasient i 50-årene hadde vært plaget med invalidiserende smerter i høyre kroppshalvdel etter et thalamusinfarkt snaut 20 år tidligere. Han ble langvarig fulgt opp av flere smertespesialister. Smertelindringen var ikke tilfredsstillende til tross for blant annet høye doser av ulike analgetika samt utprøvning med intratekal morfin og ziconotid.

Implantasjon av motorcortexstimulator er en behandling som har vist å ha effekt hos $50-75 \%$ av selekterte pasienter med ulike smertesyndromer (1). Inngrepet er ikke blitt utført i Norge. Hos denne pasienten fikk vi gjennomført operasjonen i seksjonen for funksjonell nevrokirurgi på Norrlands Universitetssjukhus i Umeå, Sverige.

Bildene viser en peroperativ kartlegging av primærmotorisk hjernebark hos pasienten. Kartleggingen skjer med funksjonell
MR (fMRi)-bilder og nevronavigasjon, somatosensorisk fremkalt respons (somatosensory evoked potential, SSEP) og elektromyografi (EMG). Målet med inngrepet var å anlegge permanente elektroder over relevante områder av primærmotorisk hjernebark for å lindre kroniske og medikamentelt intraktable smerter.

Postoperativt beskrev pasienten en klar lindring, særlig i ansiktet, der han anga at smertene ble redusert med ca. $60 \%$. I tillegg har han opplevd bedring av gangfunksjon og en bedring av tyggebevegelser. Han har ikke opplevd komplikasjoner eller bivirkninger av stimuleringen.

Pasienten har gitt samtykke til at artikkelen blir publisert.

\section{Terje Sæhle}

tsahle@ous-hf.no

Nevrokirurgisk avdeling

Oslo universitetssykehus, Rikshospitalet

Terje Sæhle (f. 1977) er spesialist i nevrokirurgi. Forfatter har fylt ut ICMJE-skjemaet og oppgir ingen interessekonflikter.

\section{Litteratur}

1. Nguyen JP, Nizard J, Keravel Y et al. Invasive brain stimulation for the treatment of neuropathic pain. Nat Rev Neurol 2011; 7: 699-709.

Mottatt 4.1. 2014 og godkjent 28.1. 2014. Redaktør: Are Brean. 